\title{
German Social Democratic Economic Politics in the Light of Agenda Theory
}

\begin{abstract}
Arne Heise*
German Social Democracy is facing tremendous challenges of societal and economic changes: party dealignment, a bourgeoisification of society, the rise of media democracy, and economic and cultural globalisation. The party's reactiona third order change in its ideological objectives and a respective adjustment in its short term policy programme as the leading governing party in the redgreen coalition ( $A G E N D A$ 20Io) - is being investigated under the conditions of bounded rationality of voters and against the background of an unprecedented loss in acceptance by the electorate as well as the ordinary party member.

JEL classifications: $A$ Ig, $H$ II
\end{abstract}

\section{The Reasons for this Choice of Subject}

For some time now a discussion has been raging on the future of German Social Democracy. The discussion differentiates somewhat roughly between the straditionalists and the modernisers $\triangleleft,{ }^{\mathrm{I}}$ and this characterisation is perhaps fitting if the position of the traditionalists $\triangleleft$ is understood as the preservation of the traditional interpretations of basic Social Democratic values, while the smodernisers to changing general conditions (Seeleib-Kaiser 2004, Heise 2005). The SPD is facing huge challenges, the like of which it has not had to meet for a long time in its I4O year-old history: I. Internally it is threatened with being pushed to the breaking-point by a dispute

* University of Hamburg. The author wishes to thank the participants of the conference Rethinking Social Democracy held at Swansea University, 3I March - 02 April, 2005, and two anonymous referees for helpful comments. The usual disclaimers apply.

I For a distinction see Padgett (1994) or Egle/Henkes (2004: 176 ff.).

Correspondence address:

Prof. Arne Heise, University of Hamburg, Department of Economics and Politics, Von-Melle-Park 9, 20146 Hamburg, Germany, e-mail: Arne.Heise@wiso.uni-hamburg.de

Received 09 Jun 2004, accepted 09 Aug 2005

(C) INTERVENTION. Journal of Economics, Vol. 2 (2005), No. 2, p. 131-151 
which goes far beyond the usual arguments between the orientation of the leading elite of a governing party towards power and the orientation of the party basis towards concrete issues. In accordance with the Hirschman options (Hirschman 1970), for the first time in its history a membership vote has been launched (voice option) to commit the party leadership to the maintenance of traditional values, and at the same time the SPD is facing a wave of resignations (exit option) which is without precedent. 2. Approximately three years after the extremely narrow election victory of the red-green governing coalition in 2002 and an election result of 38 percent for the SPD, the party is losing support among the electorate to a degree previously unknown: elections to parliaments of the states (Länder) and the communes end with historical defeats, ${ }^{2}$ in the S Sunday surveys the SPD gets only 25 to 28 percent of the votes - a historical low.

The background to this development is the political reform package 'AGENDA 20IO، of the federal red-green government under Chancellor Gerhard Schröder, which combines labour market and social policy measures that are the core of the concept of a >Third Way $:^{3}$ the state should let go its solicitous clutch of its unemancipated citizens and concentrate on the encouragement of individual self-provision and self-initiative - the ractivating or enabling state instead of the ractive state of traditional Social Democratic concepts. Social justice should no longer be related primarily to outcomes (interference in the market-determined result of the distribution of income) but to the starting-point: inclusion, i.e. participation in societal processes - particularly the labour market - is, following Anthony Giddens' (1996, I998, 2000) seminal political concept of the > Third Way`, seen as a priority even if this means increasing social distinctions: social is what creates work. ${ }^{4}$

The implementation of these ideas (see Table I), which Gerhard Schröder defends with the mantra of the lack of an alternative usque ad nauseum and continual threats to resign and which he enforces on the party (and the country) top down (Luik 2004), leads to measures some of which the SPD until recently (before the general election in November 2002) explicitly rejected and that were at any rate associated more with the political ideas of the conservative political camp (Seeleib-Kaiser 2002: $493 \mathrm{f}$.): the reduction of protection against unlawful dismissal, the integration of unemployment benefits and social assistance, the sharpening of the regulations concerning the reasonableness of job offers, real reductions in pensions, the expansion of the low-wage sector, and many more.

In the following it will be attempted to explain these developments - the re-orientation of Social Democracy in its economic and social policy core competencies combined at the same time with a huge loss of support and of the ability to form allegiance - in a

2 In Saxony, once the cradle of German Social Democracy, the SPD dropped to a one-digit electoral outcome ( 9.8 percent) at the 2004 state elections - only 0.6 percentage points ahead of the neonazist NPD.

3 On the politics of the `Third Way^ see among others Hombach (2000), Schröder (2000), Blair/ Schröder (1999), Vandenbroucke (1999), Arestis/Sawyer (2003), Sandner (2003).

4 Frenzel (2003) describes this as a change from "policies against markets" via "policies within markets" to "policies favouring markets". 
Table I: The Politics of Third Wayism (AGENDA 20I0) and the Interests Affected

\begin{tabular}{|c|c|c|c|c|}
\hline $\begin{array}{l}\text { Economic } \\
\text { Policy } \\
\text { Measure }\end{array}$ & $\begin{array}{l}\text { (Alleged) } \\
\text { Effect }^{1}\end{array}$ & $\begin{array}{c}\text { Distributive } \\
\text { Effect }\end{array}$ & $\begin{array}{l}\text { Material } \\
\text { Effect on } \\
\text { "New Centre } \\
\text { Voters" }{ }^{2}\end{array}$ & $\begin{array}{l}\text { Ideological Effect } \\
\text { on "Traditional } \\
\text { Social Democratic } \\
\text { Voters" }{ }^{3}\end{array}$ \\
\hline $\begin{array}{l}\text { 1. Hartz } \\
\text { conceptsı } \\
\text { (labour } \\
\text { market } \\
\text { reforms) }\end{array}$ & $\begin{array}{l}\text { Growth of employment } \\
\text { (increase in the allocative } \\
\text { function of the labour } \\
\text { markets) }\end{array}$ & - & $\circ+$ & - \\
\hline $\begin{array}{l}\text { 2. Tax } \\
\text { reform }\end{array}$ & $\begin{array}{l}\text { Economic growth } \\
\text { (increase in performance } \\
\text { incentives) }\end{array}$ & - & + & - \\
\hline $\begin{array}{l}\text { 3. Reforms } \\
\text { of the } \\
\text { welfare } \\
\text { state }\end{array}$ & $\begin{array}{l}\text { Increase in competitive- } \\
\text { ness, securing of the } \\
\text { financeability of the } \\
\text { welfare state }\end{array}$ & - & + & - \\
\hline $\begin{array}{l}\text { 4. Budget } \\
\text { consolida- } \\
\text { tion }\end{array}$ & $\begin{array}{l}\text { Economic growth } \\
\text { (crowding in of private } \\
\text { investment) }\end{array}$ & + & $\circ$ & ०- \\
\hline
\end{tabular}

I Effect according to the Walrasian market paradigm, which is presently dominant in academia and in the media, see for a reference e.g. IW (ed.) (2005: $275 \mathrm{ff}$.).

2 "New centre voters" understood as "members of the careerist milieu, of the new groupings of employees and self-employed, particularly in the information and service industries" (Grundwertekommission 1999), who conduct "pocketbook voting".

3 »Traditional Social Democratic voters« understood as socio-tropically voting supporters of a distributive workers' society.

$+=$ positive/advantage,$-=$ negative/disadvantage,$\circ=$ not unequivocal, $\circ+=$ tendency towards advantage, $\circ-=$ tendency towards disadvantage

Source: IW (ed.) 2005; own calculations

model of bounded rational behaviour. In order to do so, first, in contrast to the traditional rational or public choice model, which will not be used here because of its numerous consistency problems, ${ }^{5}$ an agenda model will be developed in some detail (Part 2), which promises to be able to take better account of the particular features of modern democracies the characteristic of politics in a media democracy as an revent $\triangleleft{ }^{6}$ Finally, on this basis some

$5 \quad$ Only by unacceptably bending the rationality postulate can public choice theory explain why people vote at all, and the inner contradiction between well-informed r rational jokers and rational ignoramuses shows the dilemma in which a theory finds itself that wishes to make political electoral behaviour an optimising calculus.

6 Grosse Holtforth (2000) points out that the significance of the media has until now been underestimated in the public choice model. 
propositions for an interpretation of the strategic policy orientation of Social Democracy will be presented (Part 3 ) and a - perhaps daring - alternative will be proposed (Part 4).

\section{The Agenda Model - or: Economic Policy in a Media Democracy}

The public choice model attempts to escape the accusation of ideology ${ }^{7}$ levelled at political economy by placing interests on a micro-economic foundation and virtually scientificating them. The results of the public choice model - the failure of the state or of democracy, which could lead to some problematical conclusions - are presented as being svalue-free`, and the word sideology is integrated into the analysis exclusively as a signal which lowers information costs. Public choice is thus, so to speak, the new political economy of the postideological era. However, when the dominance of the public choice approach is set in contrast to its problematical assumptions and its hitherto unsolved theoretical inconsistencies, it can indeed be suspected that the result of a fundamental scepticism regarding the state may itself be assumed to be ideologically embellished. ${ }^{8}$

\section{I The Basic Model}

Although the agenda model of political economy accepts the assumption that participants in the spolitical market (i.e. parties and voters) are guided by self-interest, at the same time it assumes that voters have only incomplete information and can therefore at best vote in a sbounded rational way. Against this background ideologies (i.e. positive visions of society and thus the object of cognition of political economy) become unrenounceable supports for decisions in a complex environment. Ideologies supply patterns of interpretation in an increasingly complex world. Parties are then not simply service enterprises own concept of the world - a sort of sblack box`, which can be filled with the preferences of the median voter - that submit their political tenders, but producers of ideologies which aspire equally, via clear sbranding , to both long-term allegiance (regular voters) and the maximisation of votes. ${ }^{9}$ Finally, the preferences of the voters under these conditions cannot

7 The accusation of ideology is always made when group or class-specific interests are postulated as relevant to the behaviour of the state actors, without this being adequately proven empirically or theoretically. »Ideology" is then translated as the conscious misinterpretation of social events; it becomes the cognitive subject or a substitute for cognition.

8 Lars Udehn (1996: 194 f.) remarks on this: »The main function of the assumption of self-interest seems to be ideological, in the sense that it favours market solutions [...] - at least according to traditional economic analysis, which sees in the market the sole institution with the wonderful ability of turning private vice into public virtue. In politics, on the contrary, it leads to suboptimal waste and serfdom. Ergo: the best society is a free market society."

9 Occasionally the dissolution of socio-structural ties (milieus) to parties (dealignment) is considered to mean the end of ideological branding. In fact, however, the opposite is true: the less the 
be assumed to be given exogenously, and pure 'pocketbook voting ‘ can neither be assumed to be a realistic nor a generally valid behaviour. ${ }^{\text {Io }}$

The voting behaviour of the electorate depends on a whole number of factors - sociostructural conditioning (milieus which create party loyalties), qualifications and the capacity to digest information, ${ }^{\text {II }}$ a hegemonial concept of society which can be regarded as given in the short term (macro-climate) and dominant (economic) policy paradigms which can change in the short term - which may, of course, vary over time in their weighting and characteristics and which vary considerably individually. The lower the qualification and the ability to digest information of the individual voter, the greater the dependence on ideologies or other rationales which determine behaviour (e.g. party loyalties and party identification) - it can therefore be assumed that the median voter is the least ideologically committed (he needs the ideology as a behavioural crutch the least) and the most typical spocketbook voter`.

Figure I: Bi-modal Distribution of Voters by Ideological Distinction

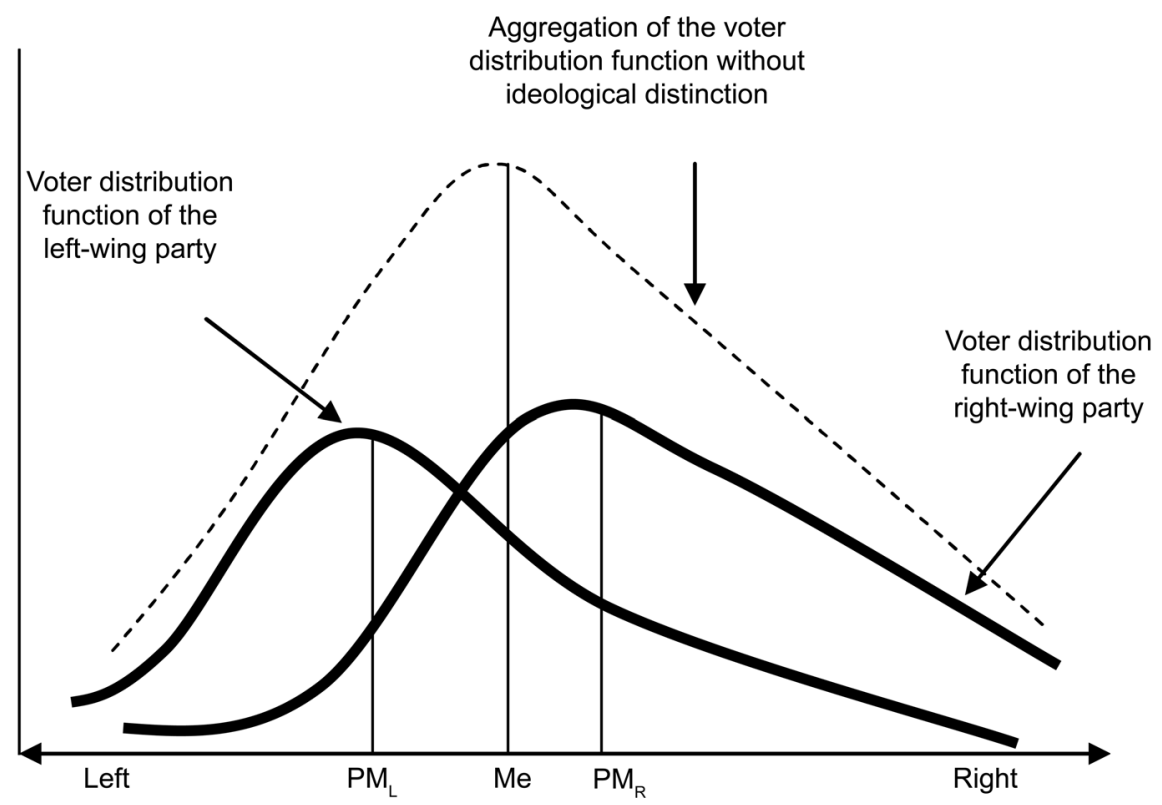

influence of the milieu, the more important are the ideological ties in the form of `brands` or ssignals` (von Beyme 2000).

Io The agenda approach shares this conclusion with the directional theory of voting behaviour (see e.g. Rabinowitz/MacDonald I989, MacDonald/Rabinowitz 1993). However, the >directional theory< underrates considerably the influence of mass media in agenda setting.

II Qualifications and the ability to digest information are only proxies for basic requirements for the rational dealing with the political choice of vote. It is certainly not intended to claim that the more highly qualified make sbetter voting decisions that the less qualified. 
Figure 2: Bi-modal Distribution of Voters in Germany

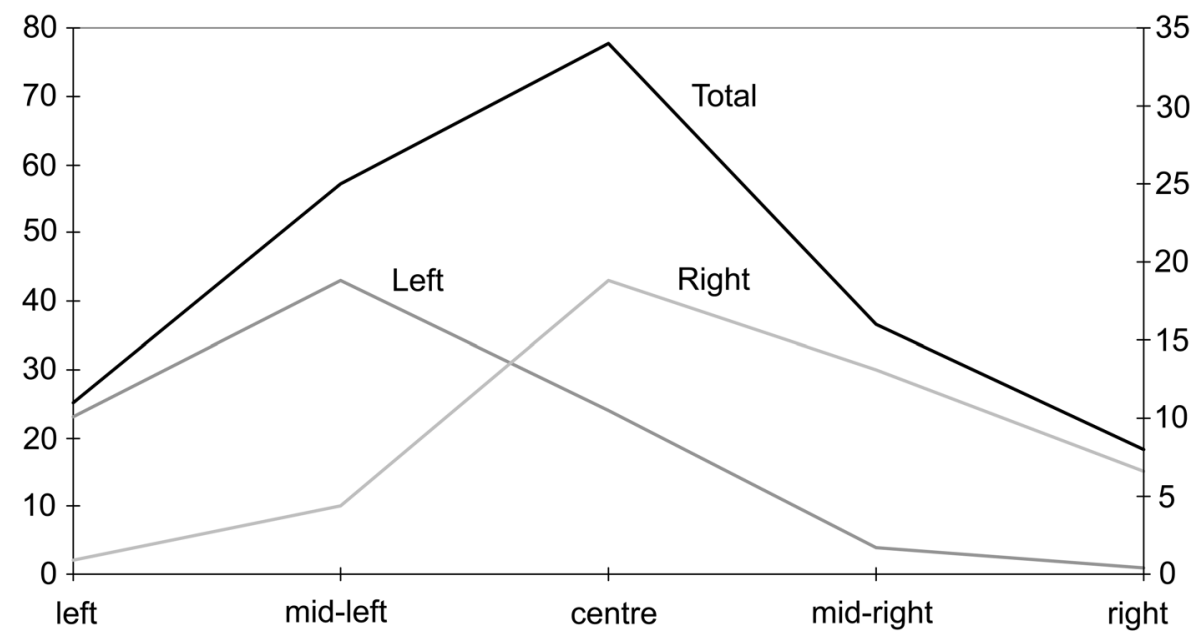

Notes: The figures show the party preferences of West German SPD- (Left) and CDU-Voters (Right) and the total electorate in aggregation as measured by the Polis institute in 1998. Left scale: SPD- and CDU-Voters in per cent of corresponding electorate; right scale: total electorate.

\section{Source: Schaub 1998: 100}

Under these conditions, however, the median voter will lose his power of influence to the party median voter. We only need to assume that behind the usually assumed unimodal distribution of voters there is a clear ideological distinction (formation of camps) with a largely insulated electorate (see Figures I and 2). The centripetal tendency of party programmes towards the median voter is now not at all certain, because every ideological change of position of a party towards the median voter and away from the party median voter (regular voter) involves the risk of losing more votes than it gains (see section 2.2). This depends decisively, however, on the quantitative relationship between regular and floating voters on the one hand and on the mobility ${ }^{12}$ of the regular voters on the other hand. The higher the mobility of the regular voters - which can be assumed more in the case of poweroriented regular voters ('chancellor election club) than in that of regular voters oriented towards concrete issues - the lower is the risk of an undue loss of votes and therefore the greater is the median voter's power of influence.

In a world in which the voting decisions of individuals are determined to a large degree by the ability of the parties to sell their policies - and this implies ideological visions (concepts of the world and models) just as much as programmes for action in the medium term (for day-to-day political activity) - i.e. to make them into a brand which creates 
long-term allegiances, particular importance attaches to communication and, in particular, the communication media. Whereas the communication media previously consisted of traditional forms such as print media, party meetings and personal networks (which is why the party members played a major role as multipliers), today we can concentrate largely on the modern mass media such as TV, newspapers and the internet. Media are not a sneutral transmitter between the parties and the voter: they filter and form to a decisive extent the information and ideological positions that they transport according to various criteria:

- $\quad$ basic ideological position (this holds true essentially for media tied to parties or religious institutions)

- $\quad$ economic interests (the media as an enterprise, but also the media as sstage-setting agencies which are looking for customers)

- basic ideological position of the media elites. ${ }^{13}$

In Table 2 the different levels of communication are summarised schematically (Sarcinelli / Schatz 2002): the media assume responsibility for the process of agenda setting , i.e. they communicate political agendas (issues, contents, appraisals) to the voters, and the policy agenda setting, i.e. they inform the political parties as to spublic opinion`. The parties are left only with agenda formation, i.e. the attempt to get certain issues and their articulation (see section 2.3) onto the list of issues that are accepted by the media as agenda setters, and to submit interpretations. In the policy agenda building process the political party, in turn, must keep its ear tuned to the voter; here the entire process becomes reflexive, because the policy orientation of the voters is in turn essentially determined by the agenda setting of the media.

Table 2: Interaction of Media, Parties and Voters

\begin{tabular}{ll}
\hline Direction of the Effect & \multicolumn{1}{c}{ Process } \\
\hline Parties $\rightarrow$ media & agenda building \\
Media $\rightarrow$ parties & policy agenda setting \\
Media $\rightarrow$ voters & agenda setting \\
Voters (lobbies) $\rightarrow$ parties & policy agenda building \\
\hline
\end{tabular}

The central role of the media - occasionally the term "Media Democracy» (»Mediokratie») is used (e.g. Meyer 2002) - now becomes obvious (they participate in three out of four processes), particularly since the political parties de facto no longer have their own, unfil-

I3 The concept of the elite is difficult to define precisely. In the research on elites these are those circles of people that are in a position to have a definitive influence on political and economic decisions; see e.g. Bürklin et al. (1997), Hartmann (200I). 
tered access to the voters, and the voter has almost no possibility of procuring information rat first hand. The central role of the media, however, also forces (economic) policy to become subordinate in a way that has been described as "colonisation" and makes the agenda setting and the agenda building process into a kind of "politainment" (Doerner 200I). This places particular demands on (economic) policies that are far beyond any rational economic expediency:

- $\quad$ the stage-setting potential of the content of politics (symbols, novelty etc.)

- the stage-setting ability of the political elites (promoters)

- the campaigning ability of the political party as an organisation.

The general situation in society now comes into focus, in which the media-managed agen$\mathrm{da}$ building and agenda setting process takes place: hegemonial societal models or concepts (macro climate) such as collectivism or individualism, scepticism of the market or the state, solidarity or competition, must first be assumed to be given for the political process based on election cycles. The macro climate is a kind of perception filter, a policy constraint. In addition there exist dominant issue frameworks` or policy programmes (micro climate) such as supply- or demand-oriented policies, the stabilisation of prices or the business climate, deficit spending or zero deficits, in the formation of which the media play a decisive role. Between the micro and macro climates there are clearly recognisable relationships of internal consistency, but no direct dependencies ${ }^{14}$ - we will turn to this again in section 2.3 .

\subsection{The Concept of the Loss Function}

The basic models of both the public choice and the agenda approach abstract from the possibility of deliberate non-voting, of abstention or, as Albert O. Hirschman put it, the exit option of the voter. In public choice theory this is understandable to a certain extent, since it is assumed that the rational voter will always decide in favour of the party sto which he is nearest (voting by proximity) - he thus always uses his voice option. In agenda theory, however, which assumes the existence of camps based on ideologies between which voter migration is at least limited (loyalty`), an exit option has to be developed in addition to the voice option. I refer here to the work of Siegfried F. Franke (2000: 53 ff.) and the fundamentals quoted there.

The starting-point is again a bi-modal distribution in a left-right spectrum. In addition to the voter distribution functions, loss functions are introduced (dashed lines in figure 3). The loss functions describe the radius of a party and the extent of the exodus (into non-voting or even into the electorate of another party) if there is a difference between the individual point of view and the position of the party (which is determined here by the party median voter). As the party position and the preferences of the party median voter

I4 Merkel (200Ia, 200Ib) states that the macro climate limits the feasible set of policy orientations (i.e. of the micro climate). 
Figure 3: Bi-modal Voter Distribution with Loss Function

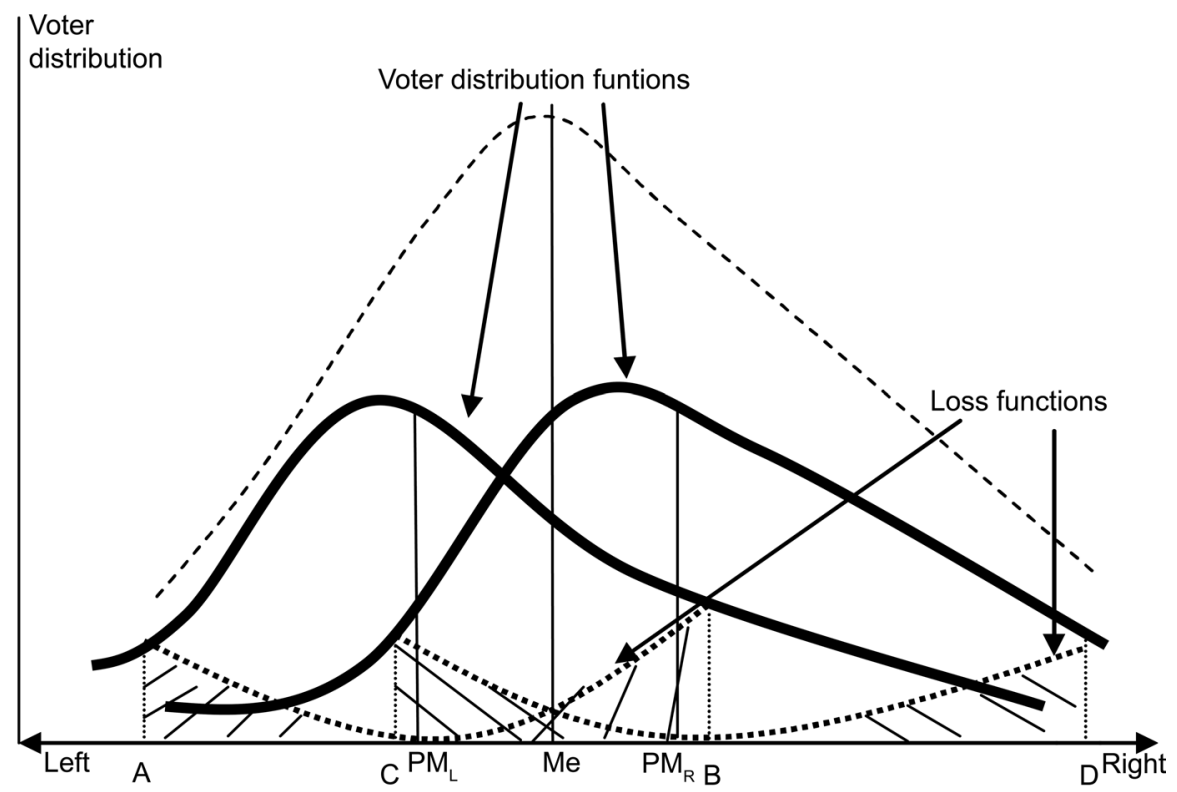

are identical, the loss function reaches zero at this point and starts increasing with the distance from the party median voter to either side of the political spectrum. In figure 3 the shaded areas indicate the respective potential loss of voters, whereby the very small area of intersection can be understood as definite non-voters, while at least those >loss-voters of the left-wing party from the right-wing spectrum could potentially become voters of the right-wing party (floating voters) and vice versa.

Figure 4 (on page I4O) depicts the effects of a shift in party ideology from $\mathrm{PM}_{\mathrm{Lr}}$ to $\mathrm{PM}_{\mathrm{L}_{2}}$ in the direction of the median voter Me. With the scentring of the left-wing party there is a change in the loss function (bold dotted line) and a change in the radius from $\mathrm{AB}$ to $\mathrm{A}^{\prime} \mathrm{B}^{\prime}$ - it is assumed here that the ideological mobility of the party members and supporters is quite low, which does not seem unrealistic for the members and supporters of left-wing parties who are interested in concrete issues. It is immediately convincing that the loss of voters - which consists largely of disappointed voters who migrate into the group of non-voters - is clearly greater than the gain of voters in the centre - which is determined by an increase in voters in the right-wing spectrum and the rawakening of non-voters. Nor should too much hope be placed on floating voters (from the potential of the right-wing party, which is not examined in further detail here), as the loss function of the right-wing party in this spectrum (see figure 3 ) is small. 
Figure 4: Loss of Voters due to a Change in Party Ideology

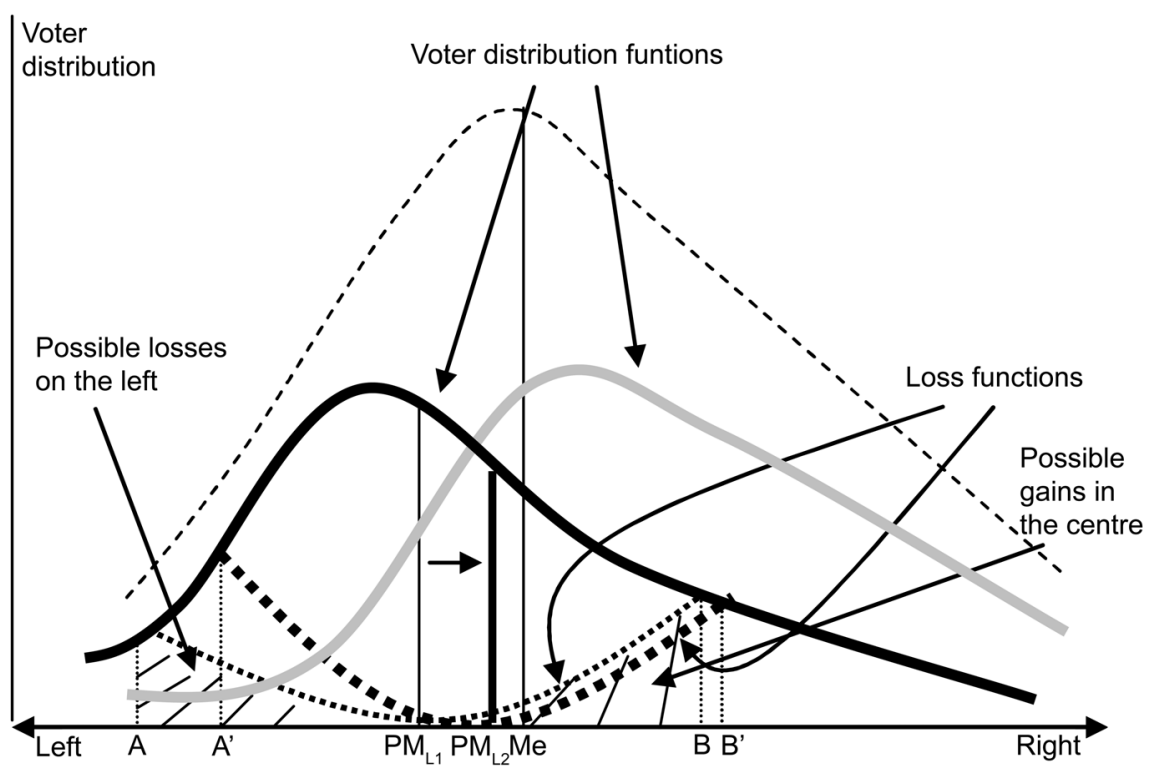

\subsection{The Framing Concept of Economic Policy}

In agenda theory two concepts that we have not yet examined in detail play a particular role: the macro climate and the micro climate. We have defined the macro climate as dominant models and concepts of the world, which as a spolitical constraint describe a framework for perception that is given in the short term. The micro climate was described as spublic opinion $<$ - essentially created by the media - and the ruling or hegemonial policy programmes, which make up the agenda setting process. The framing concept can now grant us some insight into this part of economic policy marketing between agenda building and agenda setting.

By sframing ' we mean the "simplification of complex structures and their evolving into decision alternatives" (Seibel 2002: 225; own translation) or a "general construction of situations, processes and appraisals of an imagined construed reality (Ebert 200I: 25I; own translation). ’Framing is therefore a process of communication, which provides the perception of problems, their interpretation (at the policy level), the supply of instruments and the mise en scène in an intricate, complex world (an overwhelming supply of information and a limited capacity to absorb it) between the appearance of (economic) problems and the contest between them (via economic policy). As a rule, we differentiate between different types of frame as different preliminary structures of the construed reality that are based on one another: 
Frame type I: This takes (economic) policy concepts as base lines for the interpretation of reality in the form in which they emerge directly from the activity of the government or within the framework of which we perceive government activity.

Frame type II: The actors involved - political parties, their representatives and associations (lobbies) - attempt to achieve interpretation certainty by means of ideological distinctions, value judgements etc. By creating connotations, they give themselves a sbrand image which creates bonds in the strust market of politics.

Frame type III: This consists of the great, societal concepts of basic values, which are only seldom explicitly spoken of - at least in the political process oriented towards the short to medium term - but about which there is a non-verbal preliminary understanding.

The metacultural frame type III largely corresponds to the macro climate; frame type II determines the ideological location (and marketing) of the political parties - this type of frame, too, shows a considerable inertia since an ideologically vacillating party can offer little certainty of interpretation and will therefore hardly be able to gain confidence. However, some frames of type II are certainly able to change in the medium to long run, if for example frame type III contains a change in societal values and guiding principles. Frame type I, finally, determines the perception framework in which (economic) policy takes place or in which it can be empowered to act. It describes something akin to the formation of scommon sense as a pattern of interpretation and as a rationale for activity. In the extension of the agenda building process it is therefore important not only to identify and address economic policy goals, i.e. to put them on the political agenda ("that what is talked about" and for which solutions are expected), but also to form (or to frame) the perception of problems and thus to set a precedent for approaches to solutions and frames of type II.

The success of a largely uniform neoliberal framing process (type I), which can be explained by the problems of alternative (Keynesian) framing in the stagflation phase at the end of the 1970s, the increasing dominance of the neoclassical-monetarist paradigm in academia and in political consulting (e.g. by the Sachverständigenrat, i.e. the German Council of Economic Advisors), and the increasingly uniform acceptance of this interpretation of reality by the mass media, can also be seen, finally, in the fact that a number of neoliberal assumptions - e.g. the inability of national macro-policy to act in the era of globalisation, the zero deficit as the guiding rule for financial policy, and many others - obtain wide-spread agreement even deep within the Social Democratic leadership (e.g. Meng 2002: 98 ff.).

\subsection{Critical Evaluation}

The agenda theory of political economy largely severs the band between zweckrational (instrumentally rational) policy orientation and the reality of (economic) policy, which is tied to specific interests or to society. It is not, however, the inability of autopoietic subsystems to communicate and control, as in Luhmann's system theory, which enforces this insight, but the power of the mass media to communicate and to set the stage (symbol politics; Edel- 
man I97I). Neither the fundamental capacity to control nor the necessity of control will be contested here, therefore, but the willingness to control of the (economic) policy actor in the sense of a zweckrational orientation ('general welfares).

The essential problem with the agenda approach of political economy lies in the fact that it is unable to supply a prescriptive theory that could make prognoses concerning clear election results or policies. It therefore succeeds at best in making tentative statements and supplying perspectives concerning election tactics. ${ }^{\text {I5 }}$ But it is nevertheless able to provide interesting insights into the extent to which (economic) policy programmes for action actually become politically powerful and effective. This depends essentially on the following:

- Whether and how a political programme (policy level) is subservient to the infotainment requirements of the media.

- What serves the interests of the media as economic enterprises and as tendency enterprises. The greater the economic orientation of the media enterprises (as opposed to the ideological orientation of party media or religious media), the stronger is the enterprisefriendly bias of the agenda setting process (»systematic happiness of the capitalists«; Dowding 1996: 7I ff.).

- How large the homogeneity of the opinion-forming elites in the media, parties and associations is. The more heterogeneous the social origin and the socio-cultural environment, the more dissonant is the micro climate and the more ideologically diffuse the societal macro climate.

\section{Social Democracy between Orientation towards the Median Voter and Ideologising - Some Strategic Conclusions ...}

(Economic) policy cannot be understood as the zweckrational implementation of necessities under continually changing general conditions. This view can probably even be followed by political professionals such as the German Chancellor Gerhard Schröder or the Federal Economics Minister Wolfgang Clement. Their continual references to alleged necessities must not, therefore, be interpreted as the expression of a firm belief in the purposive functionality of government activity, but is, rather, part of a communication and marketing strategy: here the pragmatic doer, the moderniser of /Germany Inc. । is created and at the same time agreement within the party to shard choices - political measures that tend to damage some (previous?) regular voters in the short run, then to improve their lot (see table I) - is demanded. This is particularly important because hidden behind the modernisation and reform policies of the `Third Way` is not only a change in the economic and

I5 This does correspond, however, to the usual demands that can at best be made of the analysis of voter behaviour and that can only be fulfilled e.g. in the standard reference to Social Democracy (Kitschelt 1994). 
social policy instruments but a new interpretation of Social Democratic values and visions (Seeleib-Kaiser 2002). ${ }^{16}$

Gerhard Schröder is attempting to lead the SPD to a new course, which is intended to preserve its long-term ability to govern. In line with his own experience of life - and the role of such personal factors in the formulation of government and party activity should not be underestimated (Meng 2002: $47 \mathrm{ff}$.) - he places more faith in strongly individualistic and meritocratic elements than until now has been regarded as desirable by Social Democrats. ${ }^{17} \mathrm{He}$ sees in this the ,feasible set of Social Democratic policies (frame type II) in the neoliberal, globalised era (under the conditions of hegemonial neoliberal frame types I and III) - i.e. in view of objective and subjective changes in the general conditions and political restrictions (Merkel 200Ia, 200Ib). Schröder and the pragmatists who determine policy cannot imagine placing themselves outside of the discourse that is defined by almost all societal elites (frame type I) or even contributing to keeping the societal discourse open and plural. Is, then, the acceptance of neoliberal hegemony the inevitable way for Social Democracy at the beginning of the $2 \mathrm{I}^{\text {st }}$ century ${ }^{18}$ Must the party accept the hard choices`, the logic of necessity of the world market, just as the Godesberg ${ }^{\text {19 }}$ Social Democracy needed the definitive abandonment of its Marxist roots as a prerequisite for long-term success - without leading this to a final splitting of the party?

From the point of view of agenda theory this change in Social Democratic party ideology - which in its convergence towards the preferences of the median voter may also be understood as de-ideologising - and in the programme of action for the medium term (AGENDA 20IO) is consistent if in the course of the >bourgeoisification ‘ of German society in fact a new party median voter type has arisen, whose interests (preferences) are clearly different from those of the previous party median voter (the ssmall man', who was addressed by the people's party of the I970s and I980s) (Duerr/Walter 200I) and who is

I6 Even the famous revisionism debate of the early 2oth century and the discussion of the Godesberg Programme were essentially discussions about instruments (property, the market and state intervention) and not about the objectives of Social Democratic politics. According to Peter Hall's (I993) categorisation, until now it has been a case of changes of the first (instrument setting) or second order (instruments), but only the spolitics of Third Wayism ‘ can be understood as a change of the third order (objectives).

I7 Franz Walter (2003: 52) describes this characteristic in the following words: "A group that from a subordinate position at first behaves in a very emancipative way, that is very determined and full of energy in putting forward its own objectives, finally achieves these objectives, rises up, leaves the position of subordinance, and now builds a new establishment. In the moment of its own success [...] it becomes conservative, defends its new status. It frees itself not only mentally and culturally, but also defends what it has achieved in a socially aggressive way - against those who have not succeeded. Aggressively the new rising stars distance themselves from those who have not kept up. And they do not want to pay maintenance for those left behind, because they have nothing to gain by doing so« (own translation).

I8 Kitschelt (1994: $287 \mathrm{ff}$.) can be interpreted in that way.

I9 At the Godesberg convention, the SPD accepted a party programme in 1959 which deliberated it from a Marxist interpretation of the world. 
converging towards the (ideologically non-committed) median voter. The Schröder SPD does in fact seem to be firmly convinced of this, when in strategy papers it states that precisely this concentration on the small man s will not be able to produce majorities in the future any longer. ${ }^{20}$ The components of the economic and social policies of the 'Third Way, presented in table I are therefore directed consistently towards the material interests of this new clientele. The loss of support which can nevertheless be observed can be explained against this background by the fact that with the loss of party distinctions as a result of the convergence of the party ideologies the quality of craftsmanship of the business of politics and - particularly important in a market such as the politics market - the trust in the credibility of the actors involved are becoming increasingly important characteristics for differentiating between what is actually indistinguishable. The long list of deficiencies in craftsmanship ("they simply don't know how to do it«) and the breaking of election promises (e.g. the promise not to combine unemployment benefits with social assistance payments was explicitly broken under the AGENDA 20I0) then lead to the (perhaps only short-term) withdrawal of confidence.

On the other hand, however, the considerations of the agenda model imply for the Social Democracy that the SPD should place greater emphasis again on its programmatic discussion than some of the leading pragmatists claim: particularly the SPD was always a party guided by concrete issues and values, which understood itself not only as a basis for power (Walter 2002: 259, Kitschelt 1994: I64 ff.). In this case, however, clear socio-political visions are an essential part of the sbrand: with ssolidarityı, sequality of opportunity and social justicer the SPD has been in possession of widely known and accepted values for more than a century, which in the present political arena can still be understood as essential characteristics of the SPD alone. However, it must be accepted that the interpretation of these values can undergo changes in the course of time, and the profile of the party will depend essentially on the extent to which it succeeds in making these interpretations visible and understandable as well as powerful in action. The Social Democracy of the Godesberg Programme threw class-struggle ballast over board by endeavouring to realise the above values within a capitalist society and by posing the question of the instruments instead of the question of the system, which was increasingly felt to be unrealistic: with "social policy«, »full employment" and "co-determination« the values could be concretised and finally, with "institutionalised Keynesianism«, a set of economic and social policy instruments could be supplied - a "gift from heaven", as Adam Przeworski (1985) once called it. ${ }^{21}$

"In the election campaign of 1998 the social groups were discovered anew which were to support this modernisation: the occupational categories of the 'new centres. The SPD election manifesto named them: highly qualified workers, forward-looking and committed managers and entrepreneurs, innovative and flexible small businessmen, craftsmen and self-employed, courageous founders of new firms, excellently educated computer specialists, doctors and engineers, inventive technicians and scientists « (Vester 2000: I7 f.; own translation.)

2I In the concepts of agenda theory the straditional Social Democratic economic policy of the Godesberg Programme supplied the fitting frame type II, which harmonised optimally with the hegemonial model of solidaristic collectivism of the 1960's and 1970's (frame type III) and the dominant 
The re-interpretation of these values by the >Third Way`-SPD in the sense of a shift from an active, harmonising social policy to an activating social policy that strengthens social distinctions, from full employment to pure employability and from participative co-determination to the exclusively locationally oriented concept of human resource management has to date apparently spread little fascination, is (still) not understood by the majority as a project that provides meaning and identity, and in the creation of the concept of >civil society ‘ has so far also been unable to develop any visionary power. Gerhard Schröder's surrender of the post of party chairman to Franz Müntefering in early $2004^{22}$ can therefore be interpreted as an attempt to present the reform `of the third order ( values) as a necessary adjustment of the instruments (AGENDA 20IO) to the continuingly valid values (reform 'of the second order ) in order to reconcile the party median voter with the median voter (i.e. to increase - positively subliminally - the ideological mobility of the party median voter). At least in the short term the calculation does not yet seem to have worked, but it is still too early to judge this strategy's chances of success.

\section{4. ... and an Alternative Interpretation}

The analyses of voter mobility in the past elections, which brought considerable losses for the SPD, on the one hand seem to be in contrast to such an interpretation: instead of a mass desertion to the conservative political camp in the political centre, the abstention of many traditionally regular voters can be observed (see figure 5 on page I 46 and table 3 on page I47). On the other hand the basic assumption of the change in the position of the party median voter is highly disputed (Vester 1999). And finally, Gerhard Schröder's resignation from the party chair would hardly be understandable if the spolitics of the Third Way s were in fact a reflection of changes in the preferences of the party median voter. ${ }^{23}$ Rather, it can be suspected that it is the processes of voter migration indicated in figure 4-particularly between the group of regular voters and the non-voter camp - that can be observed in Germany since the federal elections of 2002. The numerous resignations from the party ${ }^{24} \mathrm{can}$ also be interpreted as an expression of the shift in the `reach of the party and as a utilisation of the exit option for protest in view of the shift of party ideology away from the preferences of the party median.

\footnotetext{
interpretations of reality of standard Keynesian origin (frame type I). Accordingly, in the 1960's and early 1970's, the SPD won about 350,000 in membership ( +55 percent) and about 20 percentage points in overall electoral votes. In 1972, the SPD received 73 percent of the votes of all unionised blue collar workers; see Schroeder (2004: 74 ff.).

22 Franz Müntefering is regarded as a very sdown to earth Social Democrat - which may be taken as straditional in the distinction made above.

23 In that case the communication strategy would have needed to be changed, but not the personnel.

24 According to a study of the POLIS institute of electoral research, in 2002 and 2003 the party lost 65,000 members (about Io percent), in the first three quarters of 2004 another 40,000 left, see NOZ (2004).
} 
Figure 5: Mobility of Social Democratic Voters in Recent Elections (2003-2005)

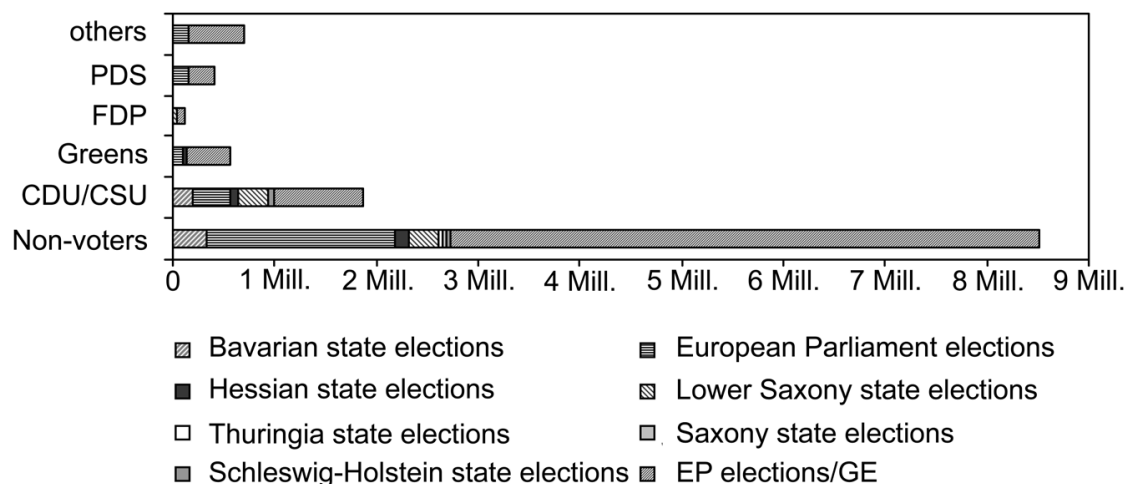

Note: Net mobility of SPD voters as compared to previous election. Bavarian state election in September 2003, Hessian and Lower Saxony state elections in February 2003, European Parliament elections in June 2004, Thuringia state elections in June 2004, Saxony state elections in September 2004, Schleswig-Holstein state elections in February 2005, comparison of EP elections (2004) and federal elections in September 2002 (net of lower voter turnout).

\section{Source: Infratest dimap, various election reports}

It would then not simply be Schröder's endeavour to manage the SPD top down as if it were a political enterprise that goes against the grain in large sectors of the membership and the potential voters, but it would also be the fundamental course - the >AGENDA $2010<$ - that would present problems, at least according to the considerations of the agenda model: with the explicit abandonment of (its own) ideological positioning the political management renounces a necessary unique characteristic, without which it will be difficult to position a sbrand with the power to create permanent allegiance. This deficit is particularly fatal if the spolitics concept of medium range places its bets essentially on reforms as an objective in themselves, as a symbol of decisiveness and the ability to act. Especially when the social reforms attack established positions in the sense of 'hard choices and thus have an effect on income distribution policy, for a Social Democratic government it is a question of survival that it is trusted to be able to maintain the social balance - and at least at present there is very much to indicate that the Social Democratic Party median voter continues to demand this (ideological immobility; see table I). The turn towards the new centre voter has not been followed (so far) by the party median voter and has been punished with migration into the non-voter camp (see figure 4). The party chairman Franz Müntefering as a new integration figure will equally have problems if the party median voter suspects that he is only a /figurehead ‘ of ` Third Wayism` or if the courted median voter fears a turning away from his preferences (e.g. through symbolic actions such as his controversial `capitalism critique`).

The clear profession of an ideological alternative in the party spectrum, however, only has a likelihood of success according to the agenda model if this positioning can take place 
Table 3: Electoral Failure of the German Social-Democratic Party (Elections Since 2004; Change as Compared to Previous Election)

\begin{tabular}{|c|c|c|c|c|}
\hline & EP Elections & Thuringia & Saxony & Schleswig-Holstein \\
\hline Overall $^{1}$ & $-9.2(21.5)$ & $-4.0(14.5)$ & $-0.9(9.8)$ & $-4.4(38.4)$ \\
\hline \multicolumn{5}{|l|}{ Education } \\
\hline High & -7 & -2 & -1 & -1 \\
\hline Medium & -8 & $\underline{-6}$ & $\underline{-2}$ & -2 \\
\hline Low & -12 & -5 & 1 & $\underline{-9}$ \\
\hline \multicolumn{5}{|l|}{ Profession/Status } \\
\hline Blue collar worker & $\underline{-16}$ & $\underline{-6}$ & $\underline{-5}$ & $\underline{-12}$ \\
\hline $\begin{array}{l}\text { White collar } \\
\text { worker }\end{array}$ & -9 & -4 & 0 & -4 \\
\hline State employee & -7 & 4 & $\underline{-3}$ & -5 \\
\hline Self employed & -6 & -2 & $\mathbf{0}$ & -1 \\
\hline Farmer & -4 & & & -3 \\
\hline Pensioner & -9 & -3 & 2 & -3 \\
\hline In education & -6 & -1 & -1 & 10 \\
\hline Unemployed & $\underline{-15}$ & $\underline{-6}$ & -1 & 2 \\
\hline
\end{tabular}

I In brackets: final result; underlined figures show above-average losses, bold figures show below-average losses.

\section{Source: Infratest dimap, various election reports}

without weakening the reach of the party on the right-wing periphery too much (the centre of the ideological spectrum; see figure 2). This danger naturally exists, however, in a 'hostile framing environment. ${ }^{25}$ Therefore, if we take the media's need for setting the stage as our starting-point, and if, on the other hand, we dispute neither the general neoliberal framing of the issues (frame type I) nor the individualistic meritocratic macro climate (frame

25 This experience was made by the SPD in the first phase following the assumption of government in 1998 under the then party chairman and Federal Finance Minister Oskar Lafontaine. And the most recent election in Northrhine-Westphalia in May 2005, once a Social Democratic stronghold, proved the risks: Again, the Social Democratic Party has not only lost votes ( -5.7 percent) but also office - after a widely received and discussed ranti-capitalistic campaign started by Franz Müntefering. The result is compelling: Unlike previous elections, the SPD has not lost to the non-voter's camp but gained 130,000 votes. Yet, this was clearly outnumbered by the electoral swing towards the CDU (-290,000 votes) and the newly established left-wing Wablalternative für Arbeit und Soziale Gerechtigkeit (WASG; -50,000 votes). And once the increase in voter turnout is taken into account $(+780,000$ votes), the gross increase in formerly non-voters turns into a net loss to the non-voter's camp $(-160,000)$. This seems to suggest, along the lines of the proposed Agenda theory, that Müntefering's 
type III), then Social Democracy must at least engage in a discourse on modernisation (reform of the second order) and cannot simply return to the instrumentation (i.e. the simple defence) of the 'Keynesian welfare state of the old type. This means both the orientation towards a distinctively distributive objective and the paying of attention to new instruments of macro-economic intervention and socio-political reform and their powerfully symbolic mise en scène in the media. Besides the filling with content ${ }^{26}$ this also means the willingness to define issues independently - this is commonly described as 'political leadership and demands the authenticity that the Schröder SPD was able to present in the event of the Iraq conflict (decisive for the last election).

\section{A Brief Summary}

On the basis of the agenda model of political economy it was attempted to explain the ideological change in the German Social Democratic Party under Gerhard Schröder towards a new centre position and the concrete formation of its programme of activity for the medium term (the AGENDA 20IO) under the conditions of the bounded rationality of voters in a media democracy, and the parallel loss of votes by the SPD.

It became apparent that the development is logical, i.e. politics capable of achieving a majority is now only possible within the (increasingly uniform) framework of issues determined by the media if it lastingly influences not only the standpoint of the median voter but also that of the party median voter. Under these conditions electoral success depends essentially on the party's power to set the scene, and the loss of votes is due to massive innerparty communication problems and weak craftsmanship.

However, the empirical consideration of voter migration and party resignations indicates that another interpretation is possible: if the ideological mobility of the party median voter - despite indoctrination by the media - remains limited, the relinquishment of a clear ideological positioning can be understood as the renunciation of a social compass and signal function, which is punished by the loss of brand allegiance.

anti-capitalist move has been taken as a signal only by those regular voters who were eagerly waiting for a chance to return, but was not seen as convincing by many other regular voters who have severely lost faith in the Schröder-Müntefering SPD. On the other side of the political reach, many voters attracted by Schröder's pragmatism (mirrored by the SPD prime minister of Northrhine-Westphalia, Peer Steinbrück) had been scared away by the shrilly tunes. One more aspect becomes very clear: trust and confidence is easily lost (at the left and right ends of the political reach) but very troublesome to regain.

26 See Arestis/Sawyer (1998) or Heise (200I). 


\section{References}

Arestis, Philip/Sawyer, Malcolm (1998): Keynesian Policies for the New Millennium, in: Economic Journal, Vol. I08, No. 446, pp. I8I-I95

Arestis, Philip/Sawyer, Malcolm (2003): `New Consensus`, New Keynesianism and the Economics of the `Third Way‘, in: Hein, Eckhard/Heise, Arne/Truger, Achim (eds.), NeuKeynesianismus. Der neue wirtschaftspolitische Mainstream?, Marburg, pp. 227-243 Beyme, Klaus von (2000): Parteien im Wandel, Wiesbaden

Blair, Tony/Schröder, Gerhard (1999): The Third Way/ Die Neue Mitte, reproduced in Hombach (2000), pp. I57-I77

Bürklin, Wilhelm/Rebenstorf, Hilke et al. (1997): Eliten in Deutschland. Rekrutierung und Integration, Opladen

Doerner, Andreas (200I): Politainment. Politik und Unterhaltungskultur in Deutschland, Frankfurt on the Main

Dowding, Keith (1996): Power, Buckingham: Open University Press

Duerr, Tobias/Walter, Franz (200I): Ohne Traditionen keine Modernisierung - die schwierige Erneuerung der SPD, in: Schroeder, Wolfgang (ed.), Neue Balance zwischen Markt und Staat?, Schwalbach/Ts, pp. 163-186

Ebert, Werner (200I): Die diskurstheoretische Sicht kooperativer Wirtschaftspolitik im Reframing-Modell, in: Frick, Siegfried/Penz, Reinhard/Weiß, Jens (eds.), Der freundliche Staat. Kooperative Politik im institutionellen Wettbewerb, Marburg, pp. 233-269

Edelman, Murray (197I): Politics as Symbolic Action. Mass Arousal and Quiescence, Chicago: Markham Publishing Company

Egle, Christoph/Henkes, Christian (2004): In Search of Social Democracy - Explaining the Politics and Policies of the Schröder Government 1998-2002, in: Haseler, Stephen/Meyer, Henning (eds.), Reshaping Social Democracy. Labour and the SPD in the New Century, London: European Research Forum, pp. 163-192

Franke, Siegfried F. (2000): (Ir)rationale Politik? Grundzüge und politische Anwendungen der ökonomischen Theorie der Politik, 2nd edition, Marburg

Frenzel, Martin (2003): Neue Wege der Sozialdemokratie - sozialliberaler Minimalkonsens oder christdemokratische Kopie? Eine Erwiderung auf Martin Seeleib-Kaiser; in: Politische Vierteljahresschrift, Vol. 44, No. I, pp. 86-93

Giddens, Anthony (1996): Beyond Left and Right, Oxford: Polity Press

Giddens, Anthony (1998): The Third Way: The Renewal of Social Democracy, Oxford: Polity Press

Giddens, Anthony (2000): The Third Way and its Critics, Oxford: Polity Press

Grosse Holtforth, Dominik (2000): Medien-Aufmerksamkeit und politischer Wettbewerb. Eine Public-Choice-Analyse der Beziehung zwischen Medien und Politik, Berlin

Grundwertekommission der SPD (1999): Dritte Wege - Neue Mitte, Sozialdemokratische Markierungen für Reformpolitik im Zeitalter der Globalisierung, Berlin

Hall, Peter A. (1993): Policy Paradigms, Social Learning, and the State. The Case of Economic Policymaking in Britain; in: Comparative Politics, Vol. 25, No. 3, pp. 275-296 
Hartmann, Michael (200I): Der Mythos von den Leistungseliten, Frankfurt on the Main Heise, Arne (200I): New Politics. Kooperative Wirtschaftspolitik für das 2I. Jahrhundert, Münster Heise, Arne (2005): Ende der Sozialdemokratie? Konstruktiv-kritische Anmerkungen zu einer dramatischen Entwicklung, in: Chaloupek, Günther/Heise, Arne/Matzner-Holzer, Gabriele/Roth, Wolfgang (eds.), Sisyphus als Optimist. Versuche zur zeitgenössischen politischen Ökonomie. In Memoriam Egon Matzner, Hamburg, pp. 173-188

Hirschman, Albert O. (1970): Exit, Voice, and Loyalty. Responses to Decline in Firms, Organizations, and States, Cambridge: Harvard University Press

Hombach, Bodo (2000): The Politics of the New Centre, Oxford: Polity Press

IW (Institut der deutschen Wirtschaft) (ed.) (2005): Vision Deutschland. Der Wohlstand hat Zukunft, Köln

Kitschelt, Herbert (1994): The Transformation of European Social Democracy, Cambridge: Cambridge University Press

Luik, Arno (2004): Der Putsch von ganz oben: in: STERN, 2I.10.2004, p. 64

MacDonald, Stuart E./Rabinowitz, George (1993): Direction and Uncertainty in a Model of Issue Voting; in: Journal of Theoretical Politics, Vol. 5, No. I, pp. 6I-87

Meng, Richard (2002): Der Medienkanzler. Was bleibt vom System Schröder?, Frankfurt on the Main

Merkel, Wolfgang (200Ia); Die Sozialdemokratie vor den Herausforderungen des 2I. Jahrhunderts. Politische Handlungsräume und soziale Gerechtigkeit, in: Schroeder, Wolfgang (ed.), Neue Balance zwischen Markt und Staat?, Schwalbach/Ts, pp. 65-98

Merkel, Wolfgang (20orb): The Third Ways of Social Democracy, in: Giddens, Anthony (ed.), The Global Third Way Debate, Cambridge: Polity Press, pp. 50-73

Meyer, Thomas (2002): Media Democracy: How the Media Colonize Politics, Cambridge: Polity Press

NOZ (Neue Osnabrücker Zeitung) (2004): Institut: Bei der SPD ebbt die Austrittswelle ab, OI.II.2004, p. 2

Padgett, Stephen (1994): The German Social Democratic Party: Between Old and New Left: in: Bell, David S./Shaw, Eric (eds.), Conflict and Cohesion in Western European Social Democratic Parties, London: Pinter Publisher, pp. Io-30

Przeworski, Adam (1985): Capitalism and Social Democracy, Cambridge: Cambridge University Press

Rabinowitz, George/MacDonald, Stuart E. (1989): A Directional Theory of Issue Voting, in: American Political Science Review, Vol. 83, No. I, pp. 93-I2I

Sandner, Günther (2003): Der dritte Weg als politische Theorie. Konstruktiver Pragmatismus als Programm, in: Hein, Eckhard/Heise, Arne/ Truger, Achim (eds.), Neu-Keynesianismus. Der neue wirtschaftspolitische Mainstream?, Marburg, pp. 279-296

Sarcinelli, Ulrich/Schatz, Heribert (2002): Von der Parteien- zur Mediendemokratie. Eine These auf dem Prüfstand, in: Scarcinelli, Ulrich/Schatz, Heribert (eds.), Mediendemokratie im Medienland?, Opladen, pp. 9-3I

Schaub, Gerhard (1998): Politische Meinungsbildung in Deutschland. Wandel und Kontinuität der öffentlichen Meinung in Ost und West, Bonn 
Schröder, Gerhard (2000): Postscript, in: Hombach 2000, pp. I5I-156

Schroeder, Wolfgang (2004): Social Democracy and DGB Unions, in: Haseler, Stephen/Meyer, Henning (eds.), Reshaping Social Democracy. Labour and the SPD in the New Century, London: European Research Forum, pp. 63-98

Seeleib-Kaiser, Martin (2002): Neubeginn oder Ende der Sozialdemokratie? Eine Untersuchung zur programmatischen Reform sozialdemokratischer Parteien und ihre Auswirkung auf die Parteiendifferenzthese, in: Politische Vierteljahresschrift, Vol. 43, No. 3, pp. 478-496

Seeleib-Kaiser, Martin (2004): Continuity and Change? Red-Green Social Policy After I6 years of Christian-Democratic Rule, in: Reutter, Werner (ed.), Germany on the Road to `Normalcy‘, Houndsmill/ Basingstoke: Palgrave, pp. I20-I43

Seibel, Werner (2002): Politische Lebenslügen als Self-Destroying Prophecies. Die Treuhandanstalt im Vereinigungsprozess, in: Soeffner, Hans-Georg/Tänzler, Dirk (eds.), Figurative Politik. Zur Performanz der Macht in der modernen Gesellschaft, Opladen, pp. $225-25 \mathrm{I}$

Udehn, Lars (1996): The Limits of Public Choice. A Sociological Critique of the Economic Theory of Politics, London: Routledge

Vandenbroucke, Frank (1999): European Social Democracy: Convergence, Divisions, and Shared Questions, in: Gamble, Andrew/Wright, Tony (eds.), The New Social Democracy, Oxford: Blackwell, pp. 37-5I

Vester, Michael (1999): Gibt es eine `neue Mitter? Die gesellschaftliche Basis für eine sozialdemokratische Reformpolitik, in: Argumente, No. 2-3, pp. 38-55

Vester, Michael (2000): Gibt es eine 'neue Mitter?, in: perspektiven ds, Vol. I7, No. I, pp. I7-3I

Walter, Franz (2002): Die SPD. Vom Proletariat zur Neuen Mitte, Berlin

Walter, Franz (2003): Der Wandel des Wertewandels kommt bestimmt, in: Berliner Republik, Vol. 5, No. 5, pp. $42-54$ 
